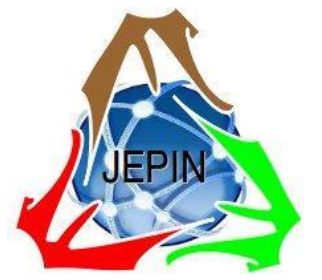

JEPIN

(Jurnal Edukasi dan Penelitian Informatika)

Vol. 7

No. 3

ISSN(e): 2548-9364 / ISSN(p) : 2460-0741

Desember

\title{
Deep Neural Network untuk Prediksi Stroke
}

\author{
Anas Faisal ${ }^{\# 1}$, Agus Subekti ${ }^{\# 2}$ \\ \#Program Studi Ilmu Komputer, Fakultas Teknologi Informasi, Universitas Nusa Mandiri \\ Jalan Kramat Raya No. 18, Senen, Jakarta Pusat \\ 114002356@nusamandiri.ac.id \\ 2agus@nusamandiri.ac.id
}

\begin{abstract}
Abstrak - Pada Tahun 2019 Organisasi Kesehatan Dunia (WHO) mendudukkan stroke sebagai tujuh dari sepuluh penyebab utama kematian. Kementerian Kesehatan menggolongkan stroke sebagai penyakit katastropik karena dampaknya luas secara ekonomi dan sosial. Oleh karena itu, diperlukan peran dari teknologi informasi untuk memprediksi stroke guna pencegahan dan perawatan dini. Analisis data yang memiliki kelas tidak seimbang mengakibatkan ketidakakuratan dalam memprediksi stroke. Penelitian ini membandingkan tiga teknik oversampling untuk mendapatkan model prediksi yang lebih baik. Data kelas yang sudah diseimbangkan diuji menggunakan tiga model Arsitektur Deep Neural Network (DNN) dengan melakukan optimasi pada beberapa parameter yaitu optimizer, learning rate dan epoch. Hasil paling baik didapatkan teknik oversampling SMOTETomek dan Arsitektur DNN dengan lima hidden layer, optimasi Adam, learning rate 0.001 dan jumlah epoch 500. Skor akurasi, presisi, recall, dan f1-score masing-masing mendapatkan 0.96, 0.9614, 0.9608 dan 0.9611 .
\end{abstract}

Kata kunci-Deep Learning, Deep Neural Network, SMOTE, Tomek links, Stroke

\section{Pendahuluan}

Stroke (Cerebro-Vascular Accident atau CVA) merupakan sebuah kondisi ketika gangguan mendadak dalam aliran darah ke otak, yang disebabkan oleh penyumbatan (stroke iskemik) atau semburan (hemoragik stroke) pembuluh darah yang membawa oksigen dan nutrisi[1]. Faktor risiko umum termasuk jangka panjang antara lain hypertensi, hyperglikemia, hyperlipidemia dan tinggi tekanan, stres emosional, dapat menyebabkan stroke. Hal ini diyakini, di bawah asumsi kedokteran, pencegahan deteksi faktor risiko ini sangat membantu untuk perawatan dini [2]. Penyediaan model yang dapat memprediksi risiko stroke akan sangat berkontribusi secara signifikan terhadap pencegahan dan perawatan dini[3]. Namun, volume data yang tinggi, heterogenitas dan kompleksitas yang terdapat pada data medis menjadi tantangan terbesar dalam memprediksi penyakit stroke.

Prediksi stroke pada pasien bertujuan untuk mengurangi potensi kematian yang disebabkan stroke. Model prediksi dengan, pembelajaran mesin telah diusulkan, antara lain menggunakan Chi-Square (Chi-2), Decision Tree [3], TwoClass Boosted Decision Tree [4], Naive Bayes, Support Vector Machine [5], Logistic Regression, Random Forest, Gradient Boosting [6]. Metoda yang diusulkan pada referensi tersebut diuji dengan menggunakan dataset yang berbeda-beda dan menghasilkan nilai akurasi yang bervariasi. Hal ini menjadi kurang tepat untuk membandingkan antar hasil dari berbagai algoritma machine learning tersebut. Hasil dari pengujian secara distributed environment didapatkan nilai tertinggi menggunakan algoritma Gradient Boosting dengan akurasi sebesar 94,49\% [6].

Selain itu, C. C. Peng, et al melakukan penelitian dengan preprocessing Feature Elimination with Cross Validation, dilakukan proses pada kondisi 1000 kali cross validation mendapatkan nilai akurasi 98\% [2]. S. Cheon and J. Kim menggunakan metode Principal Component Analysis dan pendekatan Deep Neural Network (DNN) [7]. Sedangkan A. Fitri, N. Masruriyah, T. Djatna et al juga menggunakan Artificial Neural Network untuk melakukan prediksi stroke, dengan nilai Akurasi terbaik sebesar 94,97\% [8].

Salah satu metode yang prospek untuk menghasilkan akurasi yang lebih tinggi dibandingkan dengan algoritma Gradient Boosting [9] adalah menggunakan Deep Learning. Pada Deep Learning terdapat sebuah Arsitektur dan hyperparamter yang harus dilakukan setup untuk mendapatkan nilai maksimal. Kelemahan pada [6] tidak menggunakan variasi SMOTE untuk oversampling. Berbagai variasi teknik SMOTE dapat dipilih untuk meningkatkan nilai akurasi. Pada makalah ini, kami mengusulkan metode deep learning dan melakukan preprocessing pada dataset training. Pada pre-processing dilakukan imputasi untuk menangani missing values dan teknik SMOTETomek untuk menangani imbalance class. Pemodelan arsitektur DNN dilakukan dengan menggunakan library Keras dan Back-end Tensorflow. Arsitektur dengan hyperparameter yang kami usulkan mendapatkan nilai akurasi sebesar $96 \%$, precision $96.14 \%$, recall $96.08 \%$, dan f-measure sebesar $96,11 \%$.

Makalah ini disusun sebagai berikut: Bagian II menjelaskan metode yang kami usulkan. Bagian ini membahas explorasi dataset yang digunakan sampai dengan arsitektur model DNN. Bagian III menjelaskan 
proses eksperimen dan Bagian IV membahas dan menganalisis hasil penelitian. Akhirnya, pada Bagian V, kami membuat kesimpulan hasil penelitian.

\section{Metodologi Penelitian}

Tahapan-tahapan penelitian dilakukan sebagaimana disajikan pada Gambar 1. Tahapan tersebut dimulai dari proses pengambilan data dari Kaggle sampai dengan melakukan evaluasi model prediksi menggunakan data testing.

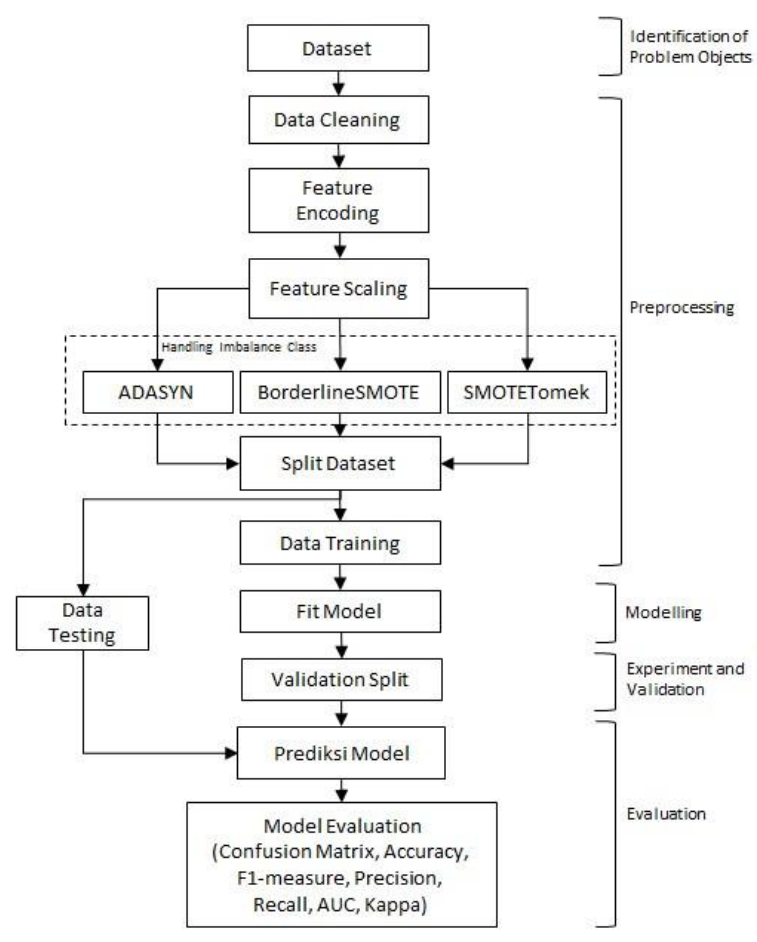

Gambar 1. Kerangka pemikiran metode penelitian

\section{A. Dataset Description}

Penelitian menggunakan dataset stroke prediction yang diunduh dari [10]. Penggunaan data tersebut agar dapat diperbandingkan dengan metode yang sudah dilakukan oleh penelitian sebelumnya, antara lain [6]. Disamping itu, penelitian dilakukan untuk mengatasi kelemahan metode yang dilakukan peneliti sebelumnya. Fokus penelitian pada kebaruan metode, sehingga akan lebih baik dengan menggunakan dataset yang sama. Data tersebut terdiri atas 5110 instan dengan 12 Atribut. Kedua belas atribut ini dapat dibagi menjadi tiga besar yaitu: atribut yang tidak dapat dikontrol, atribut yang merupakan gaya hidup dan atribut faktor risiko medis. Atribut yang tidak dapat dikontrol merupakan atribut yang melekat secara otomatis pada pasien termasuk jenis kelamin dan usia. Atribut gaya hidup merupakan kebiasaan setiap individu yang biasanya berdasarkan keinginan dan kemampuan ekonomi. Sedangkan atribut faktor risiko medis merupakan variabelvariabel yang berhubungan dengan peningkatan risiko suatu penyakit atau infeksi tertentu.

Atribut dan penjelasannya disajikan pada Tabel 1. Berdasarkan penjelasan tersebut, dataset memiliki enam atribut binary, delapan atribut dalam bentuk kategorikal dan tiga atribut dalam bentuk numerik. Sedangkan untuk informasi terkait dengan statistik deskriptif disajikan pada Tabel 2.

TABEL I

DESKRIPSI DATASET

\begin{tabular}{|l|l|}
\hline \multicolumn{1}{|c|}{ Atribut } & \multicolumn{1}{c|}{ Description } \\
\hline ID & Nomor id pasien \\
\hline Gender & Jenis kelamin pasien \\
\hline Age & Usia pasien \\
\hline Hypertension & $\begin{array}{l}0-\text { tidak hipertensi } \\
1-\text { hipertensi }\end{array}$ \\
\hline Heart disease & $\begin{array}{l}0-\text { tidak memiliki riwayat penyakit } \\
\text { jantung } \\
1-\text { memiliki riwayat penyakit } \\
\text { jantung }\end{array}$ \\
\hline Marital status & Menikah atau tidak menikah \\
\hline Work-type & Jenis pekerjaan pasien \\
\hline Residence area & Wilayah tempat tinggal pasien \\
\hline Avg-glukose & $\begin{array}{l}\text { Rata-rata level glukosa dalam darah } \\
\text { yang diukur setelah makan }\end{array}$ \\
\hline BMI & Body Mass Index pasien \\
\hline Smoking status & Status merokok pasien \\
\hline Stroke status & $\begin{array}{l}0-\text { tidak stroke } \\
1-\text { stroke }\end{array}$ \\
\hline
\end{tabular}

Pada Gambar 2, kita dapat mengamati bahwa untuk usia, rata-rata level glukosa dan indeks masa tubuh sebagai faktor yang harus dipertimbangkan dalam memprediksi kemungkinan penyakit stroke. Pada feature usia berbentuk

TABEL II

DESCRIPTIVE STATISTIC

\begin{tabular}{|l|l|l|l|l|l|l|l|}
\hline & id & age & hypertension & heart_disease & avg_glucose_level & bmi & stroke \\
\hline count & 5110.00 & 5110.00 & 5110.00 & 5110.00 & 5110.00 & 4909.00 & 5110.00 \\
\hline mean & 36517.83 & 43.23 & 0.09 & 0.05 & 106.14 & 28.89 & 0.048 \\
\hline std & 21161.72 & 22.61 & 0.29 & 0.22 & 45.28 & 7.85 & 0.21 \\
\hline min & 67.00 & 0.08 & 0.00 & 0.00 & 55.12 & 10.30 & 0.00 \\
\hline $25 \%$ & 17741.25 & 25.00 & 0.00 & 0.00 & 77.24 & 23.50 & 0.00 \\
\hline $50 \%$ & 36932.00 & 45.00 & 0.00 & 0.00 & 91.88 & 28.10 & 0.00 \\
\hline $75 \%$ & 54682.00 & 61.00 & 0.00 & 0.00 & 114.09 & 33.10 & 0.00 \\
\hline $\max$ & 72940.00 & 82.00 & 1.00 & 1.00 & 271.74 & 97.60 & 1.00 \\
\hline
\end{tabular}


unimodal yang mengindikasikan bahwa rata-rata usia yang paling banyak mengalami stroke pada usia 43 tahun dengan standar deviasi 22.61 dan hampir rata di semua usia kecuali adanya lonjakan yang tajam pada usia anak dan orang tua. Rata-rata level glukosa berbentuk bimodal dengan sedikit skew-right. Nilai standar deviasi rata-rata level glukosa sebesar 45 dan nilai rata-rata level glukosa sebesar 106. Indeks massa tubuh lebih berbentuk unimodal dan sedikit miring ke kiri (skew-left) dengan nilai standar deviasi sebesar 7 dan nilai rata-rata sebesar 128 .
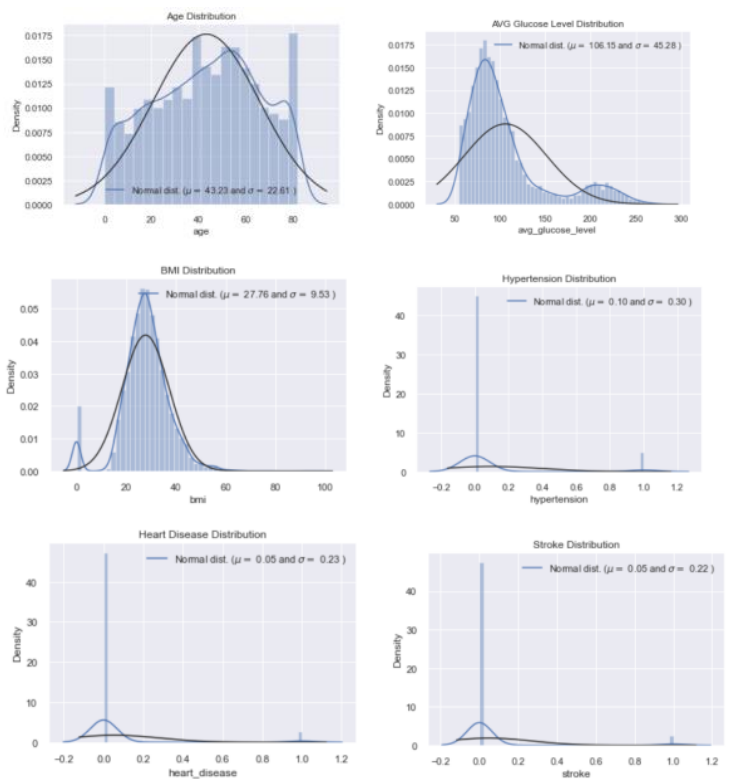

Gambar 2. Distribusi Kepadatan features

Pada Gambar 3 kita dapat mengamati pengaruh usia, indeks massa tubuh dan jenis kelamin terhadap stroke. Usia diatas 40 tahun lebih dominan terkena stroke baik pada jenis kelamin laki-laki maupun perempuan. Sedangkan pada Gambar 4 kita dapat menganalisis bahwa status merokok juga menjadi faktor yang sangat mempengaruhi terhadap stroke. Sebagian besar yang tidak stroke adalah yang tidak pernah merokok terutama pada usia dibawah 40 tahun.

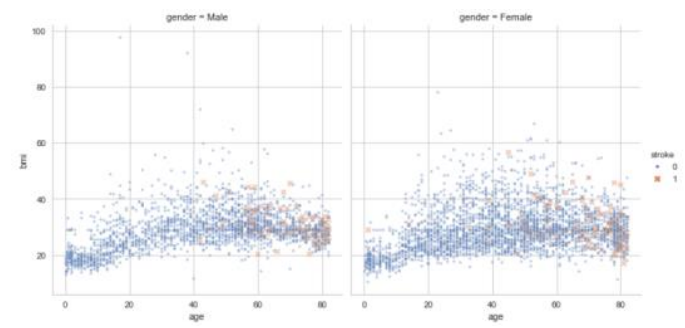

Gambar 3. Pengaruh indeks massa tubuh, usia dan jenis kelamin pada stroke

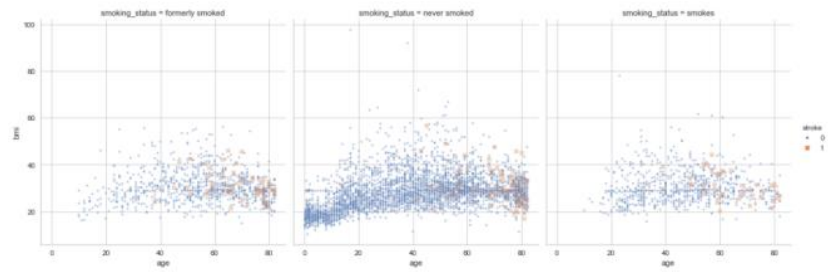

Gambar 4. Pengaruh Indeks Massa Tubuh, Usia dan Status Merokok pada Stroke

\section{B. Missing Values}

Berdasarkan observasi, dataset memiliki missing values pada tiga atribut, yaitu gender, indeks massa tubuh dan smoking status. Pada gender hanya terdapat satu instan yang tidak diketahui klasifikasinya dan langsung dilakukan imputasi dengan teknik modus. Missing values pada indeks massa tubuh sebanyak 201 instan (3,9\%) dan missing values untuk smoking status sebanyak 1544 (30,2\%).

\section{Imbalance Class}

Dataset memiliki dua target class dengan komposisi yang tidak seimbang sebagaimana disajikan pada Gambar 5. Target class 0 (tidak-stroke) sebanyak 4861 instance $(95,13 \%)$ dan class 1 (stroke) sebanyak 249 instance $(4,87 \%)$.

\section{Synthetic minority oversampling technique (SMOTE)}

Metode SMOTE diusulkan oleh Chawla et al. (2002) [11] dengan menghasilkan pengamatan sintetik untuk kelas minoritas. Untuk observasi kelas minoritas, observasi sintetik dihasilkan dalam rentang acak antara pengamatan dan k-nearest neighbor kelas minoritas. Prosedur ini dilakukan untuk setiap observasi kelas minoritas. Untuk SMOTE, jumlah k-nearest neighbor diatur ke angka 5. Meskipun SMOTE cukup efektif untuk meningkatkan akurasi klasifikasi data minoritas, tetapi masih ada masalah, antara lain terjadinya overgeneralisasi. Data sintetis yang dihasilkan oleh SMOTE masih dimungkinkan untuk menyebar pada data minoritas dan mayoritas, sehingga akan mengurangi kinerja klasifikasi. Rumus untuk menghasilkan data sintetis oleh SMOTE adalah sebagai berikut[12]:

$$
x^{\text {synthetic }}=x^{i}+\left(x^{j}-x^{i}\right) x \delta
$$

Dimana $\mathrm{x}^{\text {synthetic }}$ adalah data sintetis, $\mathrm{x}^{\mathrm{i}}$ adalah instan kelas minoritas, $\mathrm{x}^{\mathrm{j}}$ adalah instan yang dipilih secara acak dari K-nearest neighbor dari $\mathrm{x}^{\mathrm{i}}$ instan minoritas, dan $\delta$ adalah vektor di mana setiap elemen adalah angka acak dari $[0,1]$.

Pada makalah ini kami melakukan ekperimen dengan menyeimbangkan kelas dengan tiga variasi teknik SMOTE, yaitu: Adaptive Synthetic (Adasyn), BorderlineSMOTE, dan SMOTETomek links.

\section{E. Architecture Deep Neural Network}

Pada makalah ini, kami mengusulkan arsitektur $D N N$ dengan algoritma backpropagation. Model arsitektur DNN 
yang kami usulkan memiliki lima hidden layer. Pada setiap layer, kami melakukan setup hyperparameter untuk jumlah neuron, activation function, optimizer dan regularization. Pada hidden layer masing-masing memiliki neuron sebanyak 320, 288, 32, 320 dan 32 units. Activation function pada input layer dan setiap hidden layer menggunakan Rectified linear activation function (ReLu) [13], sedangkan untuk output layer menggunakan Sigmoid activation function [14]. Optimizer yang digunakan Adam [15] dengan learning rate sebesar 0,001. Untuk mengurangi overfitting, kami menggunakan teknik regularisasi dengan melakukan drop out pada hidden layer sebesar 0,2[16]. Jumlah epoch yang digunakan sebesar 500 dengan ukuran batch sebesar 96. Gambar 5 menunjukkan arsitektur DNN yang kami usulkan.

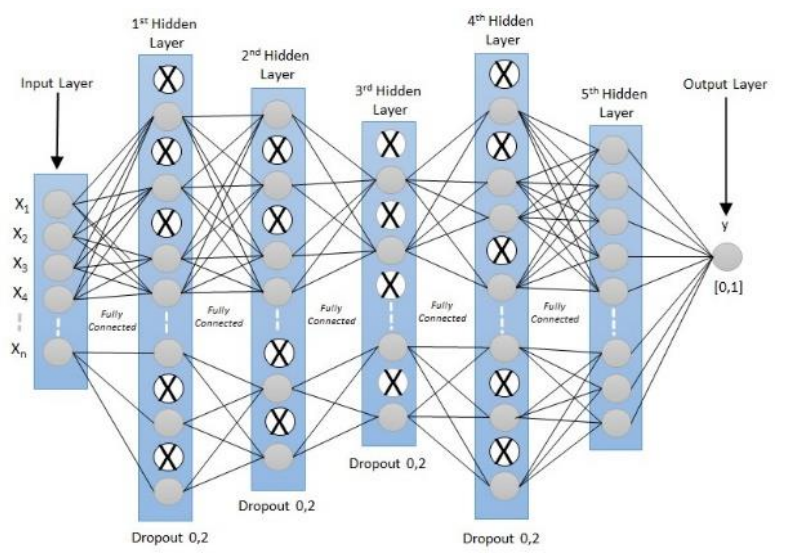

Gambar 5. Arsitektur Deep Neural Network

\section{EKSPERIMEN}

Pada bagian ini kami melakukan eksperimen dengan tahapan: 1) Pre-processing, 2) Model Eksperimen.

\section{A. Pre-processing}

Dataset yang digunakan memiliki karakteristik missing values, terdapat nilai categorical text, memiliki skala yang tidak standar dan high imbalance class. Missing values ditangani dengan mean imputation untuk feature indeks massa tubuh dan modus untuk feature status merokok. Feature yang memiliki nilai categorical text dilakukan feature encode dengan label encoding. Standarscaler digunakan untuk standarisasi data [17]. Teknik SMOTE digunakan untuk menangani ketidakseimbangan kelas[11]. Eksperimen dilakukan pada setiap model dengan menggunakan tiga teknik SMOTE, yaitu: Adasyn, BorderlineSMOTE, dan SMOTETomek. Teknik SMOTE diimplementasikan menggunakan imbalance-learn libraries.

Dataset dibagi menjadi dua bagian yaitu $80 \%$ sebagai data training dan $20 \%$ sebagai data testing. Proses pembagian tersebut dilakukan secara random. Pembagian dilakukan dengan menggunakan scikit-learn libraries [18]. Selanjutnya data training dibagi menjadi dua bagian yaitu $80 \%$ sebagai data training dan $20 \%$ bagian akhir sebagai data validation.

\section{B. Model Eksperimen}

Eksperimen dilakukan dengan membuat tiga model arsitektur DNN yang terdiri dari 4, 5, dan 6 hidden layer sebagaimana disajikan pada Tabel 3. Setiap model memiliki jumlah neuron yang bervariatif. Ketiga model kemudian digunakan untuk memproses dataset yang telah diseimbangkan dengan ketiga variasi SMOTE. Parameter Model DNN untuk fungsi aktivasi input layer dan hidden layer menggunakan ReLU dan output layer menggunakan sigmoid, jumlah epoch sebesar 400, 500 dan 600 sebagaimana disajikan pada Tabel 4. Pada proses training dioptimasi dengan Stochastic Gradient Descent (SGD), Adaptive moment estimation (Adam), dan Root Mean Squared propagation (RMSprop) dan variasi nilai learning rate sebesar $0.1,0.01,0.001$ dan 0.0001 sebagaimana disajikan pada Tabel 5 .

TABEL III

ARSITEKTUR DNN

\begin{tabular}{|c|c|c|c|c|}
\hline \multicolumn{2}{|c|}{ Model DNN } & \multicolumn{3}{|c|}{ Jumlah } \\
\hline Mdl & $\begin{array}{c}\text { Teknik } \\
\text { SMOTE }\end{array}$ & $\begin{array}{c}\text { Input } \\
\text { Neuron }\end{array}$ & $\begin{array}{c}\text { Hidde } \\
n \\
\text { Layer }\end{array}$ & Hidden Neuron \\
\hline \multirow{3}{*}{ A } & Adasyn & 10 & \multirow{3}{*}{4} & $320,256,32,96$ \\
\hline & BLSMOTE & 10 & & $320,256,32,64$ \\
\hline & SMOTETomek & 10 & & $320,256,32,32$ \\
\hline \multirow{3}{*}{ B } & Adasyn & 10 & \multirow{3}{*}{5} & $320,288,32,320,96$ \\
\hline & BLSMOTE & 10 & & $320,288,32,320,64$ \\
\hline & SMOTETomek & 10 & & $320,288,32,320,32$ \\
\hline \multirow{3}{*}{$\mathrm{C}$} & Adasyn & 10 & \multirow{3}{*}{6} & $\begin{array}{c}320,224,128, \\
32,320,96\end{array}$ \\
\hline & BLSMOTE & 10 & & $\begin{array}{c}320,224,128, \\
32,320,64\end{array}$ \\
\hline & SMOTETomek & 10 & & $\begin{array}{c}320,224,128, \\
32,320,32\end{array}$ \\
\hline
\end{tabular}

TABEL IV

PARAMETER MODEL DNN

\begin{tabular}{|l|c|}
\hline \multicolumn{1}{|c|}{ Parameter } & Nilai Parameter \\
\hline Aktivasi Input Layer & ReLU (Rectified Linear Unit) \\
\hline Aktivasi Hidden Layer & ReLU (Rectified Linear Unit) \\
\hline Aktivasi Output & Sigmoid \\
\hline Dropout & 0,2 \\
\hline Epoch & $400,500,600$ \\
\hline Batch Size & 96 \\
\hline
\end{tabular}

TABEL V

PARAMETER OPTIMASI MODEL DNN

\begin{tabular}{|c|c|c|}
\hline \multirow{2}{*}{ Optimasi } & $\begin{array}{c}\text { Learning } \\
\text { Rate }\end{array}$ & Momentum \\
\hline \multirow{2}{*}{$\begin{array}{c}\text { SGD } \\
\text { (Stochastic Gradient Descent) }\end{array}$} & 0.1 & 0.9 \\
\cline { 2 - 3 } & 0.01 & 0.9 \\
\cline { 2 - 3 } & 0.001 & 0.9 \\
\hline Adam & 0,01 & Default \\
\cline { 2 - 3 } $\begin{array}{c}\text { (Adaptive Moments } \\
\text { Estimation) }\end{array}$ & 0,001 & Default \\
\cline { 2 - 3 } $\begin{array}{c}\text { RMSprop } \\
\text { (Root Mean Square } \\
\text { propagation) }\end{array}$ & 0,0001 & Default \\
\cline { 2 - 3 } & 0,01 & Default \\
\cline { 2 - 3 } & 0,001 & Default \\
\cline { 2 - 3 } & 0,0001 & Default \\
\hline
\end{tabular}




\section{HASIL DAN PEMBAHASAN}

Dataset yang digunakan memiliki dua kelas (binary classification) yaitu: 1 (stroke) dan 0 (non-stroke). Model DNN dievaluasi dengan menggunakan standard metrics performance [19]. Metrics performance tersebut sebagai berikut: Accuracy, Precision, Recall, f1-score, dan ROCAUC.

Accuracy didefinisikan sebagai rasio antara sampel yang diklasifikasikan dengan benar ke jumlah total Sampel [20]. Accuracy dapat dihitung dengan menggunakan rumus sebagai berikut[21]:

$$
\text { Accuracy }=\frac{T P+T N}{T P+F P+T N+F N}
$$

Precision adalah rasio sampel berkategori positif yang diklasifikasi dengan benar dibandingkan dengan total sampel yang diklasifikasi sebagai positif.

$$
\text { Precision }=\frac{T P}{T P+F P}
$$

Recall adalah rasio sampel yang diprediksi positif yang diidentifikasi dengan benar.

$$
\text { Recall }=\frac{T P}{T P+F N}
$$

F1-Score merupakan rata-rata harmonik antara precision dan recall.

$$
F 1-\text { score }=\frac{2 x(\text { Precision } \times \text { Recall })}{(\text { Precision }+ \text { Recall })}
$$

ROC-AUC merupakan grafik hubungan dua dimensi antara True Positive Rate (y-axis) dengan False Positive Rate (x-axis). Metode penilaian grafis seperti ROC dan kurva Precision-Recall memberikan interpretasi yang berbeda dari kinerja klasifikasi.

Agar dapat dibandingkan dengan penelitian sebelumnya, maka salah satu metric yang digunakan sebagai dasar pemilihan model usulan prediktif yaitu accuracy score. Berdasarkan Tabel 6, accuracy score paling baik didapatkan model B dengan optimasi Adam, learning rate 0.001, jumlah epoch 500 dan teknik SMOTE SMOTETomek. Dataset yang digunakan merupakan dataset yang imbalance, metric accuracy kurang relevan karena akan menimbulkan bias. Kesalahan memprediksi kelas minoritas (False Positive-precision) biayanya lebih tinggi daripada kelas mayoritas (False Negative-recall), sehingga memprediksi kelas minoritas dengan benar (True Positive) lebih penting[19]. Namun, memilih model berdasarkan hal tersebut harus berani mengambil risiko yang diakibatkan dari tingkat kesalahan klasifikasi yang mungkin terjadi oleh masing-masing metric. Oleh karena itu, untuk pemilihan model selain menggunakan accuracy score, juga menggunakan kombinasi antara precision dan recall, yaitu menggunakan metric F1-score atau f-measure yang merupakan nilai rata-rata harmonik antara precision dan recall.
Berdasarkan Tabel 7, precision paling baik didapatkan oleh Model C dengan optimasi RMSprop, learning rate 0.01, jumlah epoch 400 dan teknik SMOTE Adasyn. Sedangkan berdasarkan Tabel 8 , recall paling baik juga didapatkan oleh Model C dengan optimasi SGD dan Adam dengan masing-masing learning rate 0.001 dan 0.0001 , jumlah epoch 400 dan teknik SMOTE Adasyn. Hal ini menunjukkan bahwa untuk precision yang nilainya paling tinggi, recall nya lebih rendah dibandingkan Model lainnya. Begitu juga sebaliknya untuk Model yang recallnya paling tinggi mendapatkan precision lebih rendah dibandingkan Model yang lainnya. Hal ini yang

\begin{tabular}{|c|c|c|c|c|c|}
\hline Optimasi & SMOTE & Model & Epoch & LR & $A c c$ \\
\hline \multirow{3}{*}{$S G D$} & Adasyn & B & 500 & 0,1 & 0,9493 \\
\hline & $\begin{array}{l}\text { Borderline } \\
\text { SMOTE }\end{array}$ & $\mathrm{C}$ & 400 & 0,1 & 0,9527 \\
\hline & $\begin{array}{c}\text { SMOTE } \\
\text { Tomek } \\
\end{array}$ & A & 600 & 0,1 & 0,9496 \\
\hline \multirow{3}{*}{ Adam } & Adasyn & $\mathrm{C}$ & 400 & 0,001 & 0,9508 \\
\hline & $\begin{array}{l}\text { Borderline } \\
\text { SMOTE }\end{array}$ & B & 400 & 0,01 & 0,9573 \\
\hline & $\begin{array}{c}\text { SMOTE } \\
\text { Tomek }\end{array}$ & B & 500 & 0,001 & 0,9600 \\
\hline \multirow{3}{*}{ RMSprop } & Adasyn & $\mathrm{C}$ & 500 & 0,01 & 0,9549 \\
\hline & $\begin{array}{l}\text { Borderline } \\
\text { SMOTE }\end{array}$ & $\mathrm{C}$ & 400 & 0,01 & 0,9553 \\
\hline & $\begin{array}{c}\text { SMOTE } \\
\text { Tomek } \\
\end{array}$ & B & 600 & 0,01 & 0,9563 \\
\hline
\end{tabular}
dinamakan trade-off precision recall [22].

TABEL VI

PERBANDINGAN ACCURACY SCORE

\begin{tabular}{|c|c|c|c|c|c|}
\hline Optimasi & SMOTE & Mdl & Epch & LR & Prec. \\
\hline \multirow{3}{*}{$S G D$} & Adasyn & B & 500 & 0,1 & 0,9131 \\
\hline & $\begin{array}{c}\text { Borderline } \\
\text { SMOTE }\end{array}$ & $\mathrm{C}$ & 400 & 0,1 & 0,9279 \\
\hline & $\begin{array}{l}\text { SMOTE } \\
\text { Tomek }\end{array}$ & $\mathrm{C}$ & 500 & 0,1 & 0,9175 \\
\hline \multirow{3}{*}{ Adam } & Adasyn & A & 400 & 0,01 & 0,9208 \\
\hline & $\begin{array}{c}\text { Borderline } \\
\text { SMOTE }\end{array}$ & A & 600 & 0,01 & 0,9368 \\
\hline & $\begin{array}{l}\text { SMOTE } \\
\text { Tomek }\end{array}$ & A & 400 & 0,01 & 0,9296 \\
\hline \multirow{3}{*}{ RMSprop } & Adasyn & $\mathrm{C}$ & 400 & 0,01 & 0,9391 \\
\hline & $\begin{array}{c}\text { Borderline } \\
\text { SMOTE }\end{array}$ & B & 400 & 0,001 & 0,9345 \\
\hline & $\begin{array}{l}\text { SMOTE } \\
\text { Tomek }\end{array}$ & B & 500 & 0,01 & 0,9337 \\
\hline
\end{tabular}

TABEL VII

PERBANDINGAN PRECISION

TABEL VIII

PERBANDINGAN RECALL

\begin{tabular}{|c|c|c|c|c|c|}
\hline Optimasi & SMOTE & Mdl & Epch & LR & Recall \\
\hline \multirow{2}{*}{ SGD } & Adasyn & $\mathrm{C}$ & 400 & 0,001 & 0,9969 \\
\cline { 2 - 6 } & $\begin{array}{c}\text { Borderline } \\
\text { SMOTE }\end{array}$ & $\mathrm{C}$ & 500 & 0,001 & 0,9845 \\
\hline
\end{tabular}




\begin{tabular}{|c|c|c|c|c|c|}
\hline Optimasi & SMOTE & Mdl & Epch & LR & Recall \\
\hline & $\begin{array}{c}\text { SMOTE } \\
\text { Tomek }\end{array}$ & $\mathrm{C}$ & 600 & 0,01 & 0,9947 \\
\hline \multirow{3}{*}{ Adam } & Adasyn & $\mathrm{C}$ & 400 & 0,0001 & 0,9969 \\
\hline & $\begin{array}{l}\text { Borderline } \\
\text { SMOTE }\end{array}$ & $\mathrm{C}$ & 400 & 0,001 & 0,9845 \\
\hline & $\begin{array}{c}\text { SMOTE } \\
\text { Tomek }\end{array}$ & A & 400 & 0,001 & 0,9957 \\
\hline \multirow{3}{*}{ RMSprop } & Adasyn & B & 500 & 0,0001 & 0,9948 \\
\hline & $\begin{array}{c}\text { Borderline } \\
\text { SMOTE }\end{array}$ & B & 400 & 0,0001 & 0,9835 \\
\hline & $\begin{array}{c}\text { SMOTE } \\
\text { Tomek }\end{array}$ & B & 400 & 0,01 & 0,9936 \\
\hline
\end{tabular}

Berdasarkan Tabel 6 dan Tabel 9, kita dapat menganalisis bahwa hasil accuracy score dan fl-score paling baik didapatkan oleh Model B dengan jumlah epoch 500, optimasi Adam, learning rate 0.001 dan teknik SMOTETomek. Metode gabungan menggunakan SMOTE sebagai teknik pengambilan sampel data dengan menggabungkan Tomek links sebagai teknik pembersihan data merupakan algoritma pre-processing yang sangat kuat untuk mengatasi masalah kelas yang tidak seimbang. Dengan menggabungkan SMOTE dengan teknik Tomek links, batas antara yang berbeda kelas dapat dengan mudah diidentifikasi[23]. Sehingga menghasilkan tingkat akurasi lebih baik. Perbandingan accuracy dan fl-score juga ditunjukkan pada gambar 6 , bahwa model B mendapatkan accuracy score dan $f 1$-score yang lebih baik dibandingkan kedua model lainnya. Sehingga model yang dipilih sebagai model prediktif adalah Model B.

TABEL IX

PERBANDINGAN F1-SCORE

\begin{tabular}{|c|c|c|c|c|c|}
\hline Optimasi & SMOTE & Model & Epoch & LR & $\begin{array}{c}\text { F1- } \\
\text { Score }\end{array}$ \\
\hline \multirow{4}{*}{ SGD } & Adasyn & $\mathrm{B}$ & 500 & 0,1 & 0,9503 \\
\cline { 2 - 6 } & $\begin{array}{c}\text { Borderline } \\
\text { SMOTE }\end{array}$ & $\mathrm{C}$ & 400 & 0,1 & 0,9539 \\
\cline { 2 - 6 } & $\begin{array}{c}\text { SMOTE } \\
\text { Tomek }\end{array}$ & $\mathrm{A}$ & 600 & 0,1 & 0,9504 \\
\hline \multirow{5}{*}{ Adam } & Adasyn & $\mathrm{C}$ & 400 & $\begin{array}{c}0,00 \\
1\end{array}$ & 0,9516 \\
\cline { 2 - 6 } & $\begin{array}{c}\text { Borderline } \\
\text { SMOTE }\end{array}$ & $\mathrm{B}$ & 400 & 0,01 & 0,9582 \\
\cline { 2 - 6 } & $\begin{array}{c}\text { SMOTE } \\
\text { Tomek }\end{array}$ & $\mathrm{B}$ & 500 & 0,00 & 0,9604 \\
\hline \multirow{5}{*}{ RMSprop } & Adasyn & $\mathrm{C}$ & 500 & 0,01 & 0,9551 \\
\cline { 2 - 6 } & $\begin{array}{c}\text { Borderline } \\
\text { SMOTE }\end{array}$ & $\mathrm{C}$ & 400 & 0,01 & 0,9563 \\
\cline { 2 - 6 } & $\begin{array}{c}\text { SMOTE } \\
\text { Tomek }\end{array}$ & $\mathrm{B}$ & 600 & 0,01 & 0,9565 \\
\hline
\end{tabular}

Model yang telah dipilih sebagai model prediktif kemudian dievaluasi menggunakan data testing dan dibandingkan hasilnya dengan penelitian sebelumnya. Perbandingan metrics performance dengan penelitian sebelumnya sebagaimana disajikan pada Tabel 10 dan Gambar 7. Berdasarkan tabel tersebut dapat dianalisa bahwa skore accuracy, precision, recall, fl-score dan AUC yang didapatkan model DNN lebih besar daripada menggunakan model Gradient Boosting.

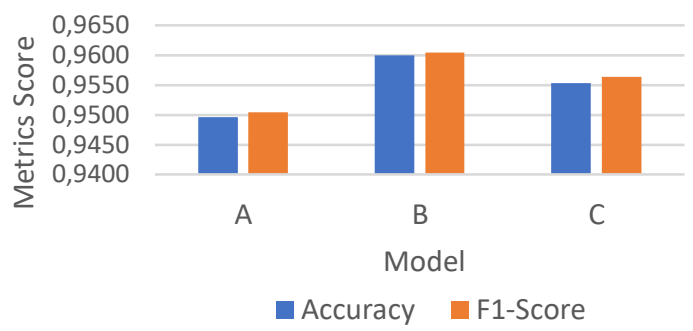

Gambar 6. Perbandingan Metric Accuracy dan f1-score antar Model

TABEL X

Perbandingan Metric Performance Model DNN DENGAN GRADIENT BOOSTING

\begin{tabular}{|l|c|c|c|c|c|}
\hline Model & Acc. & Prec & Recall & $\begin{array}{c}\text { F1- } \\
\text { score }\end{array}$ & AUC \\
\hline $\begin{array}{l}\text { Gradient } \\
\text { Boosting }\end{array}$ & 0,9449 & 0,9453 & 0,9449 & 0,9448 & 0.950 \\
\hline $\begin{array}{l}\text { Model } \\
\text { DNN }\end{array}$ & 0,9600 & 0,9614 & 0,9608 & 0,9611 & 0.981 \\
\hline
\end{tabular}

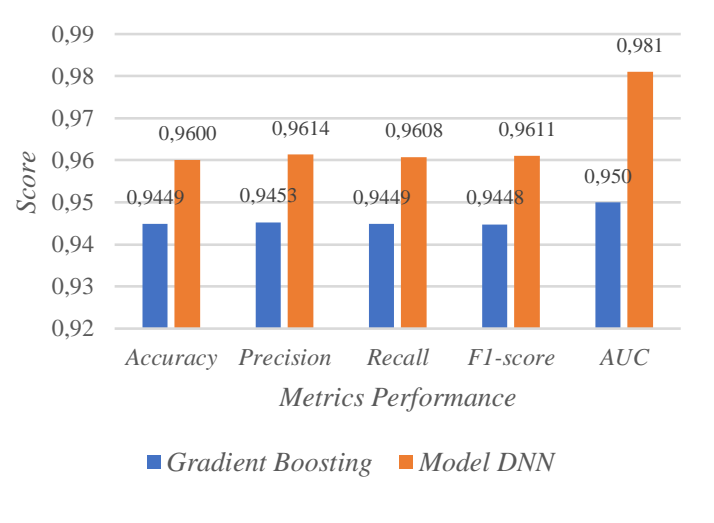

Gambar 7. Perbandingan Metric Performance Model DNN dan Gradient Boosting

Eksperimen juga memastikan bahwa model yang telah dipilih tidak over-fitting, maka dilakukan analisis terhadap grafik history training dan validation accuracy dan logarithmic loss. Gambar 8 (a) menunjukkan pergerakan history training dan validation accuracy sebelum diberikan nilai dropout. Pada Grafik tersebut menunjukkan accuracy score untuk training yang terus meningkat, namun ketika dilakukan validasi selama proses training accuracy scorenya bergerak turun. Hal ini akan mengakibatkan model lemah dalam memprediksi data diluar pola dataset training. Gambar 8 (b) menunjukkan pergerakan history training dan validation accuracy setelah diberikan nilai dropout. Grafik accuracy training bergerak naik dan disertai dengan naiknya accuracy validation, hal ini mengindikasikan bahwa model tidak over-fitting. Analisis sebaliknya dilakukan pada history logarithmic loss yang disajikan pada Gambar 9 (a) dan (b). 


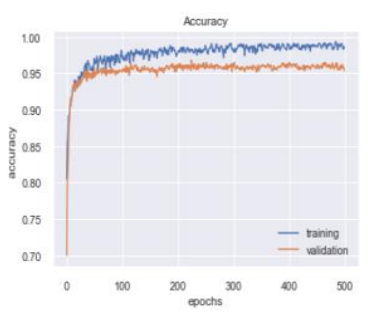

(a)

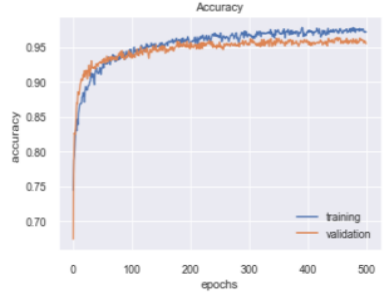

(b)
Gambar 8. Perbandingan training dan validation accuracy history sebelum dan sesudah dropout

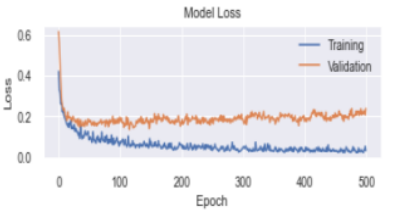

(a)

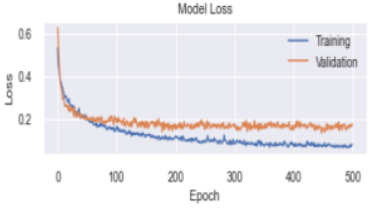

(b)
Gambar 9. Perbandingan training dan validation loss history sebelum dan sesudah dropout

\section{KESIMPULAN}

Penelitian untuk mendapatkan model prediksi stroke yang lebih baik telah dilakukan. Berdasarkan hasil model prediksi tersebut dijadikan sebagai salah satu informasi untuk memberikan saran kemungkinan potensi stroke. Dataset medis seringkali memiliki kelas yang tidak seimbang. Model arsitektur DNN yang kami usulkan dengan pre-processing SMOTE dan dikombinasikan dengan Tomek links menghasilkan performance accuracy, fl-score dan AUC sebesar 0.96, 0.9611 dan 0.981. Performance tersebut lebih tinggi dibandingkan performance model yang dihasilkan penelitian sebelumnya yang menggunakan klasifikasi Extreme Gradient Boosting.

Penelitian selanjutnya akan dilakukan dengan dataset dengan dimensi yang lebih besar, karena faktor-faktor medis sangat kompleks dan dilakukan pemodelan dengan menggunakan model deep learning lainnya.

\section{REFERENSI}

[1] A. Fitri, N. Masruriyah, T. Djatna, M. K. D. Hardhienata, H. H. Handayani, and D. Wahiddin, "Predictive Analytics for Stroke Disease," pp. 13-16, 2020, doi 10.1109/ICIC47613.2019.8985716.

[2] C. C. Peng, S. H. Wang, S. J. Liu, Y. K. Yang, and B. H. Liao, "Artificial Neural Network Application to the Stroke Prediction," 2nd IEEE Eurasia Conf. Biomed. Eng. Healthc. Sustain. 2020, ECBIOS 2020, pp. 130-133, 2020, doi: 10.1109/ECBIOS50299.2020.9203638.

[3] P. Songram and C. Jareanpon, "A Study of Features Affecting on Stroke Prediction Using Machine Learning," Lect. Notes Comput. Sci. (including Subser. Lect. Notes Artif. Intell. Lect. Notes Bioinformatics), vol. 11909 LNAI, pp. 216-225, 2019, doi: 10.1007/978-3-030-33709-4_19.
[4] S. Ray, K. Alshouiliy, A. Roy, A. Alghamdi, and D. P. Agrawal, "Chi-Squared Based Feature Selection for Stroke Prediction using AzureML," 2020 Intermt. Eng. Technol. Comput. IETC 2020, 2020, doi: 10.1109/IETC47856.2020.9249117.

[5] P. Chantamit-O-Pas and M. Goyal, "Prediction of stroke using deep learning model," Lect. Notes Comput. Sci. (including Subser. Lect. Notes Artif. Intell. Lect. Notes Bioinformatics), vol. 10638 LNCS, pp. 774-781, 2017, doi: 10.1007/978-3-319-70139-4_78.

[6] M. Rajora, M. Rathod, and N. S. Naik, "Stroke Prediction Using Machine Learning in a Distributed Environment," Lect. Notes Comput. Sci. (including Subser. Lect. Notes Artif. Intell. Lect. Notes Bioinformatics), vol. 12582 LNCS, pp. 238-252, 2021, doi: 10.1007/978-3-030-65621-8_15.

[7] S. Cheon and J. Kim, "The Use of Deep Learning to Predict Stroke Patient Mortality," 2019, doi: doi.org/10.3390/ijerph16111876.

[8] A. F. N. Masruriyah, T. Djatna, M. K. D. Hardhienata, H. H. Handayani, and D. Wahiddin, "Predictive Analytics For Stroke Disease," pp. 13-16, 2020, doi: 10.1109/ICIC47613.2019.8985716.

[9] M. Rajora, M. Rathod, and N. S. Naik, "Stroke prediction using machine learning in a distributed environment," Lect. Notes Comput. Sci. (including Subser. Lect. Notes Artif. Intell. Lect. Notes Bioinformatics), vol. 12582 LNCS, pp. 238-252, 2021, doi: 10.1007/978-3-030-65621-8_15.

[10] Fedesoriano, "Stroke Prediction Dataset," Kaggle, 2021. https://www.kaggle.com/fedesoriano/stroke-prediction-dataset (accessed Mar. 06, 2021).

[11] B. Kovács, F. Tinya, C. Németh, and P. Ódor, "SMOTE: Synthetic Minority Over-sampling Technique," Ecol. Appl., vol. 30, no. 2, pp. 321-357, 2020, doi: 10.1002/eap.2043

[12] K. A. N. and B. S. B Santoso, H Wijayanto, "Synthetic Over Sampling Methods for Handling Class Imbalanced Problems: A Review," Water (Switzerland), vol. 26, no. 2, pp. 1-72, 2017, doi: doi:10.1088/1755-1315/58/1/012031.

[13] K. He, "Delving Deep into Rectifiers: Surpassing Human-Level Performance on ImageNet Classification," Delving Deep into Rectifiers Surpassing Human-Level Perform. ImageNet Classif., 2015, doi: 10.1109/ICCV.2015.123.

[14] S. Sharma and S. Sharma, "Activation Functions in Neural Networks," vol. 4, no. 12, pp. 310-316, 2020.

[15] D. P. Kingma and J. L. Ba, "Adam: A Method for Stochastic Optimization," Adam A Method Stoch. Optim., pp. 1-15, 2015.

[16] A. Labach, H. Salehinejad, and S. Valaee, "Survey of Dropout Methods for Deep Neural Networks," 2019, [Online]. Available: http://arxiv.org/abs/1904.13310.

[17] T. D. K. Thara, P. S. Prema, and F. Xiong, "Auto-Detection of Epileptic Seizure Events Using Deep Neural Network with Different Feature Scaling Techniques," Pattern Recognit. Lett., vol. 128, pp. 544-550, 2019, doi: 10.1016/j.patrec.2019.10.029.

[18] J. Hao, "Machine Learning Made Easy: A Review of Scikit-learn Package in Python Programming Language," vol. XX, no. X, pp. 1-14, 2019, doi: 10.3102/1076998619832248.

[19] A. Liu, J. Ghosh, and C. Martin, "Generative Oversampling for Mining Imbalanced Datasets," Int. Conf. Data Min., pp. 25-28, 2007.

[20] A. Tharwat, "Classification Assessment Methods," Appl. Comput. Informatics, vol. 17, no. 1, pp. 168-192, 2018, doi: 10.1016/j.aci.2018.08.003.

[21] T. Djatna, M. Kusuma, D. Hardhienata, A. Fitri, and N. Masruriyah, "An intuitionistic Fuzzy Diagnosis Analytics for Stroke Disease," J. Big Data, 2018, doi: 10.1186/s40537-0180142-7.

[22] M. Gordon and M. Kochen, "Recall-precision trade-off: A derivation," J. Am. Soc. Inf. Sci., vol. 40, no. 3, pp. 145-151, 1989, doi: ASI1 > 3.0.CO;2-I. 10.1002/(SICI)1097-4571(198905)40:3<145:AID-

[23] F. Ri et al., "Effective Prediction of Three Common Diseases by Combining SMOTE with Tomek links Technique for Imbalanced Medical Data," vol. 2016, pp. 225-228, 2016, doi: 10.1109/ICOACS.2016.7563084. 